\title{
The Strategic Relation of Persia to British Interests
}

\author{
Rt. Hon. Sir Richard Temple Barl., G.C.S.I., C.I.E., D.C.L., LL.D., F.R.S.
}

To cite this article: Rt. Hon. Sir Richard Temple Barl., G.C.S.I., C.I.E., D.C.L., LL.D., F.R.S. (1899) The Strategic Relation of Persia to British Interests, Royal United Services Institution. Journal, 43:257, 737-751, DOI: 10.1080/03071849909423616

To link to this article: http://dx.doi.org/10.1080/03071849909423616

\section{曲 Published online: 11 Sep 2009.}

Submit your article to this journal

\section{Џll Article views: 4}




\title{
TIE STRATEGIC REEATION OF PERSIA TO BRITISH INTERESTS.
}

\author{
Bj' the RI. Hon. Sir RICHARD TEMPLE, Barl., \\ G.C.S.I., C.I.E., D.C.L , LL.D., F.R.S. \\ Wednesday, May 3rd, 1899. \\ Sir Leper. Griffix, K.C.S.I., in the Chair.
}

LET us think what is the reason why you and $I$ are here this afternoon. Surely it is Russian policy in Asia. You have all noticed in the newspapers that Russia has signed an agrecment with us upon China, which may prove to be of the most far-reaching consequence. In that respect she has behaved well, and I wish she had always done equally well. The burden of my song this afternoon will be to see whether we cannot induce her to behave in a somewhat similar manner in I'ersia. She has turned over a new leaf, we hope, in China. I can assure you that there is a very large leaf which she may with equal advantage turn over in Persia. Although I appreciate in the most friendly manner all that she has done at this moment in Clina, I must yet report to you that in Persia, and elsewhere in Central Asia, her policy has been as bad for us as it could possibly be. I do not say bad absolutely, but bad for us. No perceptible object is there in all her policy except to cmbarrass us; no advantage to her that we can see is to be gained by that policy of hers except our disadvantage. We begin to hope now, that if she does well in one part of Asia for us, she may be induced to do equally well in that part which $I$ have to bring before you this afternoon. I shall develop this point, of course.

I wish my address to-day to be taken in connection with the one that I delivered to you last autumn upon our Indian frontier. The conclusion of that address was this, that if Russia were to attempt to advance upon Herat, having scooped out-mark you, scooped out-by a bad delimitation a great piece of Afghan territory in order to get near IIerat, close also to this frontier of Persia-if she were to advance futther towards India, I showed you that she would lfave tremendous difficulti::s in the matter of supply and transport, such as would render such advance wellnigh impossible. Now, I have since been told that, appreciating these difficulties, Russia will try a new plan: she will probably follow the example of our Lord Kitchener in Egypt, and will try, in her advance upon India, to make a railway for herself as she goes along. We know the great succ os with which that was done in Egypt. I Jave had similar success dimyself in the desert near the Indus. But it is a very different matter to do anything of that kind when you have to move 100,000 men with modern armar is and all the requirements of stores and materials. What adrance sould slie make by making a railway over 
such a course as that? Mark you, 100,000 men is the least number. Say she leaves 40,000 behind her near Herat and advances with 60,000 , then there would be 20,000 to guard her rear and 40,000 to be put into line to do battle with a British army corps near Kandahar. With such a force as that, what kind of progress would she make with a railway day by day? Would she do a mile a day? I doubt it. Wven if she did that, it would take her just one year from the tinue she left her own frontier before she had the honour of seeing a British red-coat. Well, if, on the other hand, we choose to meet her, not at Kandahar, but within our own frontier, it will take her one and a half years or one and three-quarters: During the whole of that time she has to bear the strain of being at war with us all the world over. After the revelations of her Finance Minister, M. de Witte, the financial world can julge whether she could possibly bear such a strain as that. I have to repeat, gentlemen, what I impressed upon you before, and which I shall impress upon you every' time I have the honour of addressing you, that you must keep for England that great interval between Herat and liandahar as an interval which can only be passed with immense difliculty. That interial is to India as against Russia what the British Channel is for Britain as against the Continent. They are exactly the same. I mention this because there are some talented people who say what a blessing it would be if railways could be constructed right across Afghanistan, so that in the junction between the British system and the Russian system the Russians might shake hands with us in that quarter. It would be like a lamb shaking hands with the claw of a bear. It would give Russia exactly what she wants, and it would be just the same if anybody were to say, "Why, what a blessing it would be if the British Channel could be dried up, and we could drive across and sec our friends in Germany and France without going over the water! What a blessing if we could drive over dry land!" Yes, it would be very convenient in time of peace; but what would become of your safety in time of war? Think of that analogy. I assure you it exactly applies to this most important case in Asia.

I impress that upon you, because I am anxious that you should dwell on that for one moment, before I approach Persia proper with reference to that very important point on the border of Afghanistan and Persia, that is, Seistan. Now, Seistan lies exactly on that frontier a little south, or you may say considerably south, but still within a measurable distance of Herat. It is quite possible to run a railway from our Quetta, in Baluchistan, right across to Seistan, and many people have projected such a railway in general terms-and have advocated it. I have heard our English Government chided because it does not undertake it. Now, the British Government has held its hand in that respect, and I think will continus to hold it, for that is a very dangerous project. In the first place, commercially it would lead to nothing. It would be undertaken at a great cost and difficulty, and when it was done what exactly would the effect be? Seistan is a swamp and somewhat desolate, but it has been grand and fertile in former days, and would be so again under good 
administration. But what would a railway conducted thither point to ? Well, in some respects to nothing at all. First of all, it would face the great Persian Desert, and though by a caravan route it might get across the Salt Desert to Kerman-which is a very important Persian town in south-eastern Persia-or might try and work its way due south down through Mekran, that would involve. it in cnormous enginecring difficulties and ultimately lead to nothing, or at least to nothing that could not be much better approached by the sea. All these things are obvious, and show that such a railway would be of little or no use. But would it serve no other purpose? Yes : a railway towards Seistan conld be made by Russia right through Meshed in north-east Persia, starting from that very line which is advancing upon Herat, all along the northern border of Persia, that is in Turcomania. If we strained our political rights and made a railway to Seistan, then suppose Russia were to answer us by making a railway right through Khorasan, by MLshed in north-eastern Persia from her own line, that very line which is approaching Herat; why, the very thing will be accomplished which I am deprecating. We should absolutely have a junction connecting the Russian line in Turcomania with the British line in Seistan; and we should have a straight line of communication right through to Quettathat is, right up to British territory itself. At present Russia has no intention except to take her 'Turcoman line outside the British sphere. If we were to make a line to Seistan, and she were to join it as above indicated, then our position would be turned and the dividing interval, as already explained, would be lost to us indeed. 'This all-important vital interval would be bridged over in a manner more dangerous than the one I have been deprecoting. Therefore I hope that this Seistan project will never be thought of, much less undertaken, until we shall have come, if we ever do, to a definite determination with Russia--how much of Persia shall be her sphere and how much our sphere; and that is the burden of my song, as I stated at the outset. I3ut I ought to add that even if we did arrive at such an understanding, there might still be political impossibilities in any railway by. Seistan.

Now then, I shail approach Persia proper. I shall not attempt to describe to an expert audience like this the geography of that wonderful land, that ancient, romantic land. I must assume that you all know it, because I have not a moment to lose, considering the immense national arguments which I have to bring before you. But I must just remind you that Persia is bounded now on the north by the Caspian, which is a Russian lake, and the British Channel is not more under the supremacy of the British fleet than the Caspian is under the Russian military and naval arrangements. The rest of the northern frontier of Persia is bordered by a long line of railway from the Caspian to the Herat border, and north Persia is entirely overshadowed by that great means of communication. On the west Persia is bounded by what may ba called sub-Caucasia, namely, the fine tracts of Georgia with Tiflis and the like, and with the range of mountains down as far as Mount Ararat. Then on the east, of course, Persia is bounded by Afghanistan and by British 
Baluchistan. Remember, Persia has a share of Baluchistan; she is bounded there by British Baluchistan. On the south and south-west she is bounded in the most important manner for British interests, first of all by MIesopotamia and the joint stream of the Tigris and Euphrates before they run in one united volume to the Persian Gulf. 'Then in the south' is the Persian Gulf, which I have to show you is a British lake, as it ought to be, and, when we choose to make it so, is just as much British as the Caspian is Russian.

That being my general definition of the country, I wish, for political purposes, to divide Persin into two parts. First the northern, or upper, and then the southern and south-eastem, or lower part. Now, as regards the upper part, you may make up your minds that it is has become Russian irretrievably, and that not by any immediate process, but by a proces; that has been going on all through the century. Let. me, on the tips of my fingers, recount all the steps by which Russia has accomplished this great achievement, that is, the mastery-not the orershadowing supremacy, but the absolute mastery-over the upper part of Persia. First, she tore from Persia the beautiful province of Georgia, the various parts of $A$ sia Minor underlying the Caucasus. Then she picked a quarrel with Persia, and the consequence of that was, that some more bits of $A$ sia Minor were taken, adjoining Persia; and above all, the Russian dominion over the Caspian was secured. I'revious to that, it was Persia who was the mistress of the Caspian; after that it was Russin. I necd not say that this Caspian marine communication is an important link in the chain of communication which Russia has established between her European possessions and the Afghan frontier towards India. Then of course there was the Crimean War, and that developed a great deal of trouble in the Caucasus. You remember how the brave Circassians, after the war was over, were thoroughly externinated. That thoroughly consolidated the Russians' position on the great line from Europe towards India. There was Georgia conquered; the Caucasus thoronghly subdued by the extermination of the mountaineers; the conveniently situated River Araxes being made the boundary in that quarter between Russia and Persin-the entire subjugation of the Caspian-and then what came next? The subjugation of Turcomania. Now we, for a long time, had a great interest in Turcomania, and the question was whether Merv should be Russian or British.

It was too far off really for Britain, but it was comparatively handy for Russia, since she got possession of the water-carriage of the Caspian. In vain did the most far-sighted and experienced British officers in Asia warn the British nation, over and over again, that if we allowed Russia to get MIerv there would be no means of stopping her until she got to the Herat border, and that was called "MIervousness"! It really was the patriotic foresight of the bravest and noblest of the sons of England! Well, of course, we could not stop Russia going to Merv by any force we could have sent there, but we might have emplojed the whole of our British diplomatic power in Europe, and told her that if she went to Merv she would have a row with England. But we let her take it in the 
most ruthless and thoroughgoing manner by the troops of the famous General Skobeleff. From that time Turcomania was subdued, and Turcomania lay right along the north-eastern border of Persia, and brought Russin into very measurable distance of Herat.

That is a brief sketch of the progress of Russia in that quarter. After that you may as well give up that upper part of Persia as lost, as far as British influence goes. We, of course, have a Consul-General at Meshed, and as usual some command of the money market in that quarter. We hare, too, a Minister in Teheran, which comes within this upper quarter; but he is not there for the upper quarter, but to represent British interest everywhere in Persia, and his influence is derived not from any authority we have up there in the north, but from the potential power we have in the south, in the Gulf and elsewhere, as I shall endeavour to show you. So I repeat, you may as well give up at once, as past praying for, the upper part of Persia. Russia has got it. Whether it was through our neglect or not it is futile to enquire, but got it she has, and we must take the consequences and try to retrieve the misfortunes, such as they are, by our achievements elsewhere. It is the old story: Russin does one thing in one place, and we must do something more than equivalent in another; just as when she took Port Arthur we capped her by taking Wei-hai-Wei. If she has taken northern Persia we will cap her by doing the same in southern Persia, only we shall do it beneficently for the Persians. What good she has done to Persia as yet I do not undertake to say'; but I am anxious to be very fair to Russia. I speak of her without reserve, because really the time has passed for mincing matters in these grave affairs. I am willing and anxious to do her justice. I admit she has done good to Persia, to Khorasan, and IIeshed, in the north-east portion of Persia, by her conquest of Turcomania. She has stopped, in a great measure, the awful raiding that used to go on there. You have heard dreadful stories of slave-hunting in Central Africa, but I assure you those horrors are surpassed by the horrors which used to go on between Turcomania and the Persian province of Khorasan. Raiders used to come into the Persian villages, tie the women and children to the tails of the horses, and drag them helplessly into slavery across the desert. Russin has stopped that in a great degree-although I am not quite sure she has entirely stopped it -but she has stopped it in the main, and for that she deserves credit and honour from every lover of humanity. Now I say that part of Persia must be given up. Just let me enumerate what the provinces are.

Adjoining Georgia and the River Araxes there is the finest part of Persia, namely, the great lake of Urumiah, now so well known in the religious world of England on account of the Nestorian Missions which have been protected beneficently by the Church of England under the Archbishop of Canterbury. There is the lake and the province, or strip of land, between the lake and the Russian frontier and also a part of what is now the adjoining Turkish fronticr. Now, there is nothing whatever to stop Russia to-morrow from coming across the border and helping herself, without the least opposition from anybody, to that which 
is the finest, coolest, most delightful part of Persia. It was, I suppose in ancient days one of the gardens of the earth; now it is one of the fines parts of Persia and of $A$ sia. All that could be taken-also the northerr province of Persia near the Caspian, all that fine range of Elburz moun tains above Tehcran; and Teheran itself could be taken. Really-Russia might, by lifting her little finger to-morrow, have them all. The whole of Khorasan, with its headquarters at Meshed, with the sacred shrines, she has merely to walk across to take as much of it all as she likes. She does not do so now because she is afraid of having a row with England about other things. She is apprehensive of having the whole Persian question raised by England if she touches Khorasan. But she looks upon it as a ripe pear that is going to fall into her lap some day.

Now, what I want to impress upon you, my friends, is this, that without attempting to cry over spilt milk or to regret what is passed, and without any recrimination as to whose fault it was-let all that go; it has all happened and we cannot prevent it-much more is going to happen which we are also unable to prevent, and we had better make the best of it with a good grace, a smiling grace if we can, and then sec what we can do for oursclves in another direction, which shall more than counterbalance all we have lost there. 'That is the true British plan; and it is by considering where our strength lies and how we can exert it that we shall observe the best interests of our nation.

I have described to you unreservedly the upper part of Persia. Let me just mention to you the lower part of Persia. First of all let me remind.you that the basis of our power there is the sen. We have, of course, unassailable access by sea to the Persian Gulf. You go from India first of all to the Gulf of Oman. "Oman's green waters" the poet spoke of, and the fort of MLuscat, which if I can find time I will allude to bricfly, although it does not come quite within the Persian purview. Then you get to Cape Mesandom, right opposite Bander Abbas, which is the Strait of Ormuz. Now, Ormuz is one of the names most celebrated in the songs of ancient times and in the associations of medixval centuries. You get to Bander Abbas. Of course, some French journalists were good enough to tell some of our friends that Russia was going to have some interest in Bander Abbas. You might as well say that England was going to have some interest in Krasnovdsk, the great military port of Russia on the Caspian. If we allow any Russian interest at Jander Abbas we may as well give up the game altogether. Russia would not have to make such a move, or if she did, I hope the British lion would begin to roar in earnest. But I do not believe that for a moment. Bander Abbas is particularly a British port. It has always been so since it was given up by the other Powers who have long since yielded to England in the East. The trade there is entirely British, and everything there is in I3ritish hands. Then you go up the Gulf and you get to Bushire. Now, 3ushire was a point on which we landed troops in 1857 for our attack upon Shiraz, bccause Persia was threatening Herat. It was one of the means by which we compelled Persia to give way, and we made that the basis of one of our military operations. Since then, we have always 
kept a British Resident there and the British flag floats there to-day. The trade there is British-cverything there is British. There is no olher influence there but British influence, and that place is the capital of the Persian Gulf. Then in front of Bushire and not very far from it is the Isie of Karak. That island we occupied during the war, and it was a thousand pities that we gave it up after the war. We should have kept it. But now we could take it to-morrow if we wanted it. We have only to send a gun-boat and put up a British flag, and it is ours. So much for the Persian Gulf, and recollect that that has always been a Iritish lake since I can remember. We have policed it with our ships of war and we have kept down piracy. We preserved the pearl-fishing, and we have done everything a civilised Government could do to maintain something like law and order and civilisation in the Persian Gulf. If there is a British lake in the world it is the Persian Gulf-I never licard anything else. When I was Governor of Bombay if anything went wrong in the Persian Gulf a telegram was sent to $\mathrm{mc}$, and I got the Viceroj's permission and spoke to the admiral on the Bombay station, and I inmediately took measures to put an end to the mischicf. I believed certainly, and the Government which I had the honour to represent, and the Viceroy whom I had the pleasure to serve, also believed, that I was the chicf police officer of the Gulf and of those waters. Fancy telling me that any other Power is to share dominion in those important waters with my Government and my nation that I had the honour to represent!

IVell then, passing from the Persian Gulf we get to the mouth of the joint river-Shat-el-Arab-well, never mind about the name-which is the joint river of the Tigris and Euphrates. You remember those two rivers join, and then flow in one stream to the Persian Gulf. At the upper end of the Persian Gulf there is a tongte of land, at the end of which there is a place called lao. Now, Fao is getting its name mentioned in the papers nowadays. What is Fao? It is the strip of land, I beliere, upon which the Turks recently, in defiance of their treaty engagements with Persia, erected a fort.

You will remember the arrangement was that Persia was not to erect any forts on her fronticr, and Turkey was not to erect any on hers. Turkey broke her agreement by erecting this fort at Fao, and when remonstrated with by Persia calmly.told her "You can do the same on your frontier." Such. then, is Fao. Yet we were told the other day that Russia, of all people in the world, is going to attempt to have some interest at Fo! Why, Fao is a Turkish position; how can Russia do such a thing? If Turkey is going to surrender one of her positions of her Asiatic dominions to Russia she will at once have a burning question to face. You will remember that under the Treaty by which we hold Cyprus, all the Asiatic dominions of the Sultan are under the protection of Britain as against Russia. Of course, if Russia attempts to touch Fao we should have a burning question with 'lurkey. Can you believe that we shall allow Russia to touch liato? If anybody touches Fo it will be the British. 
So much for the mouth of the river. We then go up this river to Bassora, at the junction of the Tigris and Euphrates, the well-krown trading place. You go up the river, and on the left side is the Turkish boundary, and on the right is the Persian boundary, and then you get to Bassora. And what is Bassora? In my day there was always a British Agent or British Resident there, and Bassora was in essentials policed by the Government of Bombay. The first thing I recollect on taking charge of the Government was, that I got an urgent telegram from Bassora, saying there was a disturbance, and could I get a war-ship sent up the river to answer for law and order. I took the pleasure of the Viceroy and spoke to the admiral on the Iombay station, and we sent up a ship and stopped the row. This looks to me very much like a British sphere of influence and British supremacy; indeed, British dominion really. Now, before you get up.to Bassora, from the Gulf, you pass a town named MIohammera. I suppose you have forgotten that name now, but let me remind you that forty years ago it was familiar in every London newspaper, because that was the second base of our operations in the war with Persia in 1857 . Une base was at Bushire, towards Shiraz, which I have mentioned, and one was at Mohammera, near the mouth of the Karun, which is a tributary of the joint rivers of the Tigris and Euphrates, and which runs right through the south-western, or as we may call it, southern Persia, and crosses one of the finest parts of Persia. It is a navigable river. It used to be protected by great hydraulic engincering works which did honour to the ancient Persian dynasty, and all of which could now be repaired. We sent a British force up this river as far as Ahwaz, which is near where the river debouches from the mountains near Shuster. We went up this river Karun, and it was owing to these movements, in conjunction with other movements from Bushire and the Gulf, which I have explained, that.Persia was obliged to makc peace, and we-wanted her to make it quick. We needed just then every one of our soldiers to help us in the Indian Nutiny.

All these are the vestiges of British dominion which has been very powerfully enforced within the memory of half the people present here at this moment, and these are the measures which do really represent the bases of the British sphere of infuence.

Let me now consider that if I really cede-willingly cede, because you had better agree to the inevitable-the northern provinces which $I$ have already explained Rusia has got; let me now consider the provinces which by parity of reasoning I have ventured to claim for the British lion, and for the red line. Well, of course, I should like to see a line drawn right across the centre of Persia. I should begin just north of Seistan, and you will see why I dwelt at the outset so much on Seistan; naturally Seistan must be within the British sphere. Nothing should induce us to let Russia get near it. I begin north of Scistan, and then draw the line across the great Salt Descrt. There is a mighty desert in that quarter, or rather a chain of deserts. There are two deserts called Lut, with a short caravan route between them leading froin Scistan towards Kerman. Then these two deserts are divided one from another by this caravan route, and 
above that there is the great desert called Kavir, the worst desert of all, and that, of course. I would leave to Russia. But the other desert must come within the red line, because that is necessary to preserve the caravan communication between Kerman, which is really the capital of eastern Persia, and Seistan. Then I should like to draw the line going slightly to the north, up.to Yezd. I do not care about the desert, but we must have lierman within our red line. Then we must go north and have Yezd, which is the second important town in eastern Persia; and then we must draw the line straight to.Ispahan, which is the old capital-kingly, imperial capital-of Persia. The modern capital is Teheran, which has fallen hopelessly to Russia; but we will have Ispahan. Then from Ispahan you draw the line straight across to Mesopotamia, somewhat south or below what is now called Hamadan. This Hamadan is only a Persian name now, but every classical scholar will remember it was called that because it was the Ecbatana of ancient times, more especially of Alexander the Great. Everybody who has read Alexander's campaign will remember that. We draw the line from Ispahan to the Mesopotamian outlying districts by liermanshah, and I would include the districts about Disful. Now Disful lies a little to the north not far from Shuster in the Karun valley. It is of the highest possible interest. I suppose Disful is perhaps the second, if not the first-at any rate the third-most classical site in all $A$ sia. Disful was Susa. Now Susa, remember, was the capital of Darius. When Alexander yon the decisive battle of Arbela, Darius fled towards Susa. Babylon in those days lay to the south and had lost its importance. Susa was in the very acme of wealth and prosperity. It was here that the conquerors rushed, seized all the family of the vanquished Darius, and got the masses of treasure, in many millions sterling worth of silver bullion. There are the mounds still remaining which mark where once the walls and towers and temples and palaces of Susa stood in all their splendour. That is about the place which I should like the British line to include running from Ispahan to Kermanshah. Then going south, of course, we take in all the Karun country, and so we should work our way by the head of the Persian Gulf to Shiraz. Now, Shiraz is the most beautiful place in all the country of the Persians. It is the home of all their poets, all their best literature is there, and all their most beautiful scenery, and that, of course, would come within the red linc. And so we should work our way down towards our own frontier at Baluchistan. I am not drawing these points of the proposed British sphere as British dominion, but as districts withir British infuence, that is as much as 'Teheran and the other districts in the north would be under the Russian sphere. In fact, these districts are still under British infucnce, though, of course, our influence may be weakly or powerfully, effectively or ineffectively exerted ; just as Russia has the power of doing what she likes in the north, so we have the power of doing what we like in the five provinces which I have been mentioning.

If these spheres of influence are to exist, why not say to Russia, "Well, it is no good our quarrelling about Persia, and about influence in Persia: of course we assume you are not going to annex it, and of course 
we are not; but we both wish the prosperity and integrity of Persia." These are the kind of expressions always used. We might mutually guarantee all this to Persia; but neither we nor Russia could guarantec this, that Persia shall not fall to pieces by her own dead weight. You know there is a phrase "A dying nation," and certainly if there is a dying nation in the world it is Persia. Her prosperity is decreasing, her population is said to be gradually lessening; or even if it be gradually increasing, still it is infinitely less than what it once was. The sand, owing to bad arrangements, is encroaching upon some of her best places, and she is gradually giving way all round. There is no time for me to go into it this afternoon, but if I were to explain the difference between Persia of to-day and the Persia of Xerxes, Darius, and Cyrus, you would hardly believe it. I suppose there were more fighting men in the armies of Cyrus than there are male inhabitants now in all Persia. This is greatly owing to the reckless administration, to the destruction of forests, the decay of the irrigation works, and a hundred other things. You hear of "The Earth as Modified by Human Action"-a clever American book. The most signal instance of that is Persia. Yet Persia had the most magnificent territory in former times. Every schoolboy knows how grand Persia was. All that grandeur has gradually slipped away, owing to bad management. It is going, and will ere long be gone. So we should say, of course, to Russia:- "We guarantee the integrity and independence of Persia for the present ; but if Persia falls to picces, then these two spheres will be set up"-and our respective spheres might be set up cren now. We may, by those means, prop up the falling kingdom, but in the meantime we may have this agreement between the two great Powers. That is the substance and the sum total of my' discourse this afternoon. We have the power to enforce our position in the south of Persia. iVe have only to exert it. The country is near the high road to India. If we were to let Russia get to the lersian Gulf we should have an enemy on our fiank upon onc of the most important of our communications. I ask every naval and military man in the room, What is the great line of British communication in the world? Is it not that which goes through the Mediterranean, traverses Egypt, goes down the Red Sea, crosses the Indian Ocean to Ceylon, to China, to Australia, and everywhere? That would be the very line which would be threatened by having a hostile Power in the Persian Gulf. We could never tolerate it, of course. Therefore we must see to our interest in Persia. That is why, for the sake of our Indian Einpire, our Far Eastern sphere as it is going to be-for the sale of all and every interest, European and native, which we have, even in the antipodes, the eastern antipodes-for the sake of all these we must have this water communication without any sort of impediment, without anyone near our flank, in any part of it. Therefore we must stick to the Persian Gulf and everything that relates to it. And we cannot keep the position we have unless we have influence over the shores that surround it. And after all, if the Shah were to say, "I cannot stay in Teheran; the Russians are going to put an officer in the place"; we would say, "Never mind, Your Wajesty ; come to us inside 
our line; set up yourself at Ispahan ; or if you think that is too near the Russians, come down to Shiraz, the home of all that is glorious to the Persian nation." We must not say too much to His Majesty about the Persian writers, because he is not of that race himself. although he is so technically. We should have to say to him, "Come to Shiraz and the British protection, under the $x$ gis of the Queen-Kmpress, aad thre you shall set up your own throne close to all the remains of Xerxes and the monarchs of many dynasties. Come to Shirax, which is still the most classical and romantic and poetic place in the imagination of every Persian, and set up yourself there. Then you are within measurable distance of the Jritish flect, and you are safe against all comers; and then the infuence of southern Persia, by Your Majesty's kiml assistance, will be given to Ingland. We will give you position, prosperity, such as your people cannot afford, and add dignity to the home of your ancestors, and you will be perfectly safe under the protection of the invincible British flag." "That is my idlen with regard to Persia.

Now, if I have two more minutes I will say a word about Muscat. When I was asked to deliver this address I was requeste I to mention Muscat. Now Muscat, of course, is not in the Persian limits; it is round the corner of the entrance to the Persian Gulf, and really in the Sea of Oman in Arabia. But Muscat is entirely within our political sphere; it always has been within my memory, and that goes a long way back. It has alwajs been British. Its family was comnected by a sort of couninhood with the family at Zanzilsar. In my time the arrangement with the two families used to be made simultaneously. It scemed to me possibly an orersight that when we settled all French claims at Zanzibar we di.! not take the opportunity of clearing all French claims out of Muscat. France took the opportunity of clearing our interest oút of Madagascar. and she might have conceded our position in .Iuscat as will as in Zanzibar. That was not done; but never mind-Muscat is ours, and our rights must be enforced by arms if necessary. Muscat is under treaty with us. The Sultan really çannot do anything in his axternal relations without us; he cannot make any concession to any forcinn Puwer without us; and when he dared to make a concession to some French gentlemen, which, of course, was not approved of by the French-though if it had been successful it would have been approved of, and if unsuceessful disavowed-when he did that he really did incur the just displeasure of the Indian Government; and I am very glad the British, without a moment's delay, sent a man-of-war up to point its guns at the palace and to force him to give the concession up. That is what must be done and can easily be done. France gets a coal-shed, she is welcometo that ; but Muscat is absolutely ours, and that must be insisted upon. I do not suppose Russia would dream of going so far, but France might. At any rate it shows she would if she dared. That would be introducing it foreign Power into the inconvenient proximity of our great line of naval, military, and commercial communication.

Now, ladies and gentlemen, I must not detain you unduly. I hope that $I$ have succeeded in maling clear to you my meaning as to what 
our British interests in these countries are. Pray remember always that in Irritain we are ruled not only by Qucen, Lords, and Commons, but also by public opinion; and if a well-informed public opinion demands that certain of British interests be protected in a certain way, that protection will be given, no doubt, with all the might of the Empire. I trust that you will consider the growing importance of our interests in the East which are now joining on fast to our interests in the Far East. Remember that, great as these interests liave been when we were young, they are doubly or trebly greater now and likely to grow to an indefinite extent; and its extent will scverely tax all our national resources. We must omit no precaution that shall conduce to safety, leave no points unguarded that will assist us. If we allow this, that, or the other to be done by foreign nations endangering and embarrassing us, then we shall have the greater difficulty of looking after all the countries and dominions under our charge. Fien now we have enough to do if our interests are to be suarded from every possible point of vicw. But if they are insufficiently guarded, the task of maintaining our Empire in the East and the Far East will be beyond even the powers of Britain. I do think this is a very good time to try and come to an understanding with Russia in these matters, because there are classes in Russia, to my certain knowledge, who say there is not room enough for both Russia and England in Asia, when sometimes it is said there is room for both. I repeat, there is a party in Russia who say there is no room for both. That means they are to be everywhere and we are to be nowhere! $A h$, well, we will sec to that! But although there is a party of that kind, on the other hand there is a reasonable party, particularly in the banking and commercial world, who are becoming very anxious to have better relations with us, and that sentiment might very well be found in the recent utterance of $\mathrm{MI}$. de Witte, the Russian Fihance Mlinister. We can do more in the way of lending money and promoting trade, and taking for valuable consideration the products of Russia, than any other nation. Considering that we have thus a great hold upon her, we should not let so favourable an opportunity pass in coming to a thorough understanding with her. We should sufficiently guard our equal and more than equal position and interest with her throughout that great quarter of the globe which is called Asia.

The Chairmax (Sir Lepel H. Griffin, K.C.S.I.):-Before asking any, of the experts who are present, and of whom I see several well competent, to speak upon this subject, I think as Chairman you will permit me to detain you a few minutes. Not having had the opportunity of reading beforehand Sir Richard Temple's exceedingly able and eloquent address, I think, as Chairman, it is my right to take the opportunity of expressing the points in which I somewhat, with all respect, venture to differ from the-lecturer. After all, the duty of the Chairman is not absolutely confined to concurrence, and although there is no one in the room-not even Sir Richard Temple himself-who is a more confirmed Imperialist than myself, yet in dealing with a country like Persia, which is an independent monarchy of the greatest interest and importance, it is wise not to assume too much. I would not venture to criticise any of the remarks made, were I not in a position intimately to know. Persian politiss of to-day. As the Chairman of the Imperial Bank of Persia, which has alrcady done so much for the country, 
and which will, in the future, do so much more, I am fully in the position to know the state of affairs, not only in Teheran but in all other parts of the country, from which reports reach us, I may say, almost every day of the week. First, I would ask you, What are the points which struck you most in his eloquent address? They seemed to me, as I listened, to be two : first, the impossibility of England contending with Russia in the north with any degree of success; and, secondly, the supreme importance to England of the command of the Persian Gult. I think most military men present, and perhaps all of you, will agree that those are the principal points of importance. IVell, with regard to the Persian Gulf, let me say once for all that I most cordially concur in every word which Sir Richard Temple has said. The Persian Gulf is, and should remain, a British lake. It has been so since the beginning of this century, and it will be a very bad day" for England when any Government retreats from that position. This I say with no possible degree of disregard for Persian rights. Persia has no Navy, and the sea. and especially the Persian Gulf, belongs to Great Britain. The only p.int on which I wish really to express, not my disagteement with Sir Richard Temple, but a different way of looking at things, is the amount of influence, or, as he termed it, supremacy, possessed by Russin in northern Persia. There is no doubt that if you look at a map and sec the Russian frontier running from Tillis to Ashurada and Merv, right along the north frontier of Persia, you will perfectly understand that a monarch who can put three million soldiers in the field, could send his troops across the frontier and ociupy all northern Persia without our laving a word to say. Admitted. But, ladies and gentlemen, this is the nineteenth, and soon will be the twentieth, century, and I say that in the conscience of Europe there is no place for such an act of violence directed against an absolutely unresisting and innocent neighbour. These things are passing more away than you imagine. Persia is not Clina, and when there is a country with an ordered administration, speaking civilised European languages, and with diplomatic representatives in the European Courts, it is not possible for Russia, except under the very gravest provocation, and in most exceptional circumstances, to take this particular step. There is a moral objection-I do not use the word " moral" in an ethical sense, as you may imagine-but there is a strong moral objection to such a course as that. The second objection to it is that Persia and the Persian Government infinitely prefer England to Russia. This to us in northern Persia is an enormous political advantage. The Persians know perfectly well-and I wish by my voice I could press it upon you all-that England does not desire anything of Persia except an open door, the extension of her commerce, and the prosperity of the country. That is all we want, and all we shall continue to want. The Persians understand perfectly well that Russia desires more, but at the same time the Russian advance at the present time is on the same lines as our own; it is a commercial advance, and the great part of their advance $I$ do not think we need in any way grudge them. The Russians are making a road from Enzeli and Resht to Kazvin and Teheran, and an excellent thing it is that they should make it. It cloes not give them more than a commercial command of that part of the country which undoubtedly, as Sir Richard has explained, does extend probably to the latitude of Ispahan. But I say, gentlemen, that the Persian question is very much a financial question, and that is our great strength in Persia. It is a financial question. You are not going to build railways and make roads without money; and if Russia is going, as silly people in Vienna and Berlin assert, to make a railway from the north to a port on the Persian Gulf, that money' would have to be found in London, because I do not think they would find it in Paris, and they certainly will not find it in St. Petersburg. I think, gentlemen, that is all I need say. I entirely agree with Sir Richard that an understanding with Russia would be of the utmost advantage. We must be very carcful of not saying words which might excite the apprehensions of Persia that we are intending to indulge in the same sort of

$$
2 \times 2
$$


proceedings which have been associated with the name of Russia. You must remember, gentlemen, that in the last twelve years where Russia has taken one square mile of territory, England has taken sixteen ; so that it is just as well to be a little modest when criticising the procecdings of our most excellent neighbour of the North, who, as far as I can understand, does not possess that diplomatic supremacy which is so generally supposed, and which gives rise to all these ridiculous reports you see in the paper. Not Paris, but Berlin and Vienna, are the nest in which are hatched all sorts of ridiculous rumours, such as that which Sir Richard Temple has so ably attended to in connection with Bander Abbas. What would Russia do with a railway to Bander Abbas if she got it made with English capital? It would only take English goods up the country, and Russian goods would not go that way. The whole thing is preposterous, not to say, as Sir Richard Temple has asserted, that Bander Abbas is almost British territory. This I felt it my duty to say, having taken the Chair, because I feel that Persia only requires good government atnd the firm and steady support of the British Government to maintain her independence. I do not think the time has come when Russia has either the power or the will to take it from her, if England supports her as England ought to support her.

General Sir THoms GordoN:-Having been Military Attaché at Teheran, I have some knowledge of the subject of this lecture, and I shall therefore make a few remarks on what has been said. With reference to the Persian Gulf; it should be known that England is very active with her gun-boats there, and it may be said that they regularly patrol the Gulf at all seasons. In the newspapers lately, special attention was drawn to a gun-boat going up the Shat-el-Arab, the combined mouth-channel of the Euphrates and Tigris, but it is a very common thing for a gun-boat to pass up there to visit Basra, which is a favourite resort at times. The Gulf is patrolled so effectively that the Persian and Arab coast population think that England in some way supports and maintains Persia's authority in the Gulf, and this may be regarded as reason for the fact that Persia looks upon England as a good and strong friend. With reference to Fao, it is not Persia that has an engagement with Turkey regarding that place, but England on the part of Persia. The engagement is that so far as the opposite bank of the Shat-el-Arab is Persian territory, the river channel shall be the boundary between Turkey and Persia. Originally Turkey wished to claim the whole of the channel, and they were the stronger party, but England took the matter up for Persia in order to secure free navigation, and the engagement was inade that Fao should not be fortified. There is, therefore, no fort there, but only some necessary small works for the protection of the Turkish telegraph station. Regarding Turkey at Basra, she is quite strong enough there to keep the peace, as she has two corveltes on the station under a commodore, who sometimes acts as governor. There is often an expression of opinion that Russian diplomacy is superior to England's at 'Teheran. I do not think this is the case. The reason for that impression perhaps is that Russia often appears to get her own way easily in minor matters with the Persian Government; but it should be borne in mind that the members of the Persian Government always belong to Turk and Persian families of the north. All their families, properties, and personal interests are in the north, and it therefore follows that their fears and feelings are more readily influenced; but, on the whole, English diplomacy manages to hold its own in affairs of importance. As a matter of fact, England has not lost position or prestige in Persin. There is only one other point that $I$ would touch upon. The lecturer said that owing to the sad misgovernment of Persia the country had fallen away from its millions, which furmished the largest number of fighting men in the world in ancient times, to its present poor population. The number is now about $9,000,000$, and the number is increasing, not decreasing. The destruction of Persia's ancient prosperity was not due to misgovernment, but to the ruthless Arab invasion in the seventh century, followed 
by that of the Mongols in the thirteenth century. These devastated the whole country, uprooted the population, cut down the trees and destroyed the fertility of the soil to a vast extent. In the ancient times, forests and fields, habitation and cultivation formed very different landscapes from what is now to be seen. The oases were larger, and the cultivated spaces pressed more closely on the desert tracts, which in area were accordingly very much smaller. Since then the physiognomy of the land and the climate, more so especially in the south, have greatly changed, and the change has produced much of the desolation that prevails in the Persia of to-day. 